\title{
Podwójne nazewnictwo na Śląsku Cieszyńskim (Zaolziu) od czasów monarchii habsburskiej po dzień dzisiejszy
}

\begin{abstract}
The article presents the process of introduction of double naming to the Cieszyn lands, later to Zaolzie. It presents this process in the space of time from the middle of the 19th century to the present day. It devotes attention to the time of the Austro-Hungarian Empire, the interwar Czechoslovak Republic, post-war Czechoslovakia and the contemporary Czech Republic. In the context of dual naming, it draws attention to the legislative solutions of individual governments and to the use of dual naming in practice during specific periods. The article does not avoid describing sensitive issues such as the destruction of bilingual signs with double names of places and streets, or the growing wave of aversion towards Poles.
\end{abstract}

Key words: Zaolzie, Polish minority, bilingual names, Polish-Czech relations

Nazwy geograficzne w czasach nowoczesnych często były traktowane jako narzędzie władzy i wielokrotnie wykorzystywano je jako instrument walki politycznej. Przejawiało się to szczególnie w środowiskach wielokulturowych, takich jak np. Śląsk Cieszyński czy po 1920 roku Zaolzie, gdzie od dawnych wieków żyli obok siebie Polacy, Niemcy i Czesi. Często zmieniająca się przynależność państwowa tej ziemi i zmienne układy polityczne powodowały równie częste zmiany nazw miast, ulic czy innych przestrzeni geograficznych. Procesowi temu towarzyszyły znaczne emocje. Rządząca większość nadawała nową nazwę przestrzeni, którą tradycyjnie zamieszkiwała mniejszość, a to nie zawsze było po myśli tejże mniejszości. Poprzez nazwy geograficzne mniejszość wyrażała swoją 
przynależność do danego miejsca, nic więc dziwnego, że traktowała je jako ważne dziedzictwo kulturowe. Struktura narodowościowa na omawianym terenie ulegała zmianie w ciągu dziejów. Obecna czeska większość była za czasów austriackich mniejszością, Polacy zaś, którzy obecnie stanowią mniejszość na Zaolziu, byli tu kiedyś większością. Nazwy miejscowe były i są trwałymi pomnikami dziejowymi, odzwierciedlającymi specyfikę krajobrazu, jego historię, osadnictwo, ukształtowanie terenu, a także mentalność mieszkańców (Mácha, 2019, s. 1), toteż zdaniem mniejszości powinny być przedmiotem ochrony na równi z obiektami materialnymi. Ich usuwanie czy przekręcanie może doprowadzać do destrukcji krajobrazu kulturowego. $Z$ wyżej podanych powodów kwestia podwójnego nazewnictwa $\mathrm{w}$ środowiskach wielojęzycznych nie jest zwykłym zagadnieniem politycznym, ale przez to, że łączy w sobie pierwiastki polityczne i emocjonalne, zakorzenione w głębi duszy zainteresowanych, może stać się niezwykle zapalnym problemem i źródłem trwałych nieporozumień.

W niniejszym opracowaniu chcemy poświęcić uwagę kwestii podwójnego nazewnictwa na ziemi cieszyńskiej od czasów Austro-Węgier, a szczególnie Czechosłowacji i samodzielnego państwa czeskiego $\mathrm{w}$ okresie międzywojennych rządów demokratycznych, komunistycznych rządów totalitarnych oraz współczesnych rządów odnowionej demokracji. W kontekście podwójnego nazewnictwa zwrócimy uwagę na rozwiązania legislacyjne poszczególnych rządów oraz na stosowanie w poszczególnych okresach podwójnego nazewnictwa w praktyce. Celowo nie zajmujemy się okresem okupacji hitlerowskiej, kiedy temat ten przybrał charakter zagadnienia innego rodzaju. Jako źródło posłużą nam drukowane dokumenty legislatywne, literatura proweniencji polskiej i czeskiej oraz prasa lokalna.

Wytyczony temat $\mathrm{z}$ całą pewnością powinien być przedstawiony w szerszym kontekście regulacji praw mniejszościowych $\mathrm{w}$ wybranych okresach oraz polityki narodowościowej konkretnych reżimów i dążeń do stosowania szeroko pojętej dwujęzyczności, nie tylko podwójnego nazewnictwa. Autor jednak celowo rezygnuje $\mathrm{z}$ takiej obszernej koncepcji, gdyż w przeszłości już kilkakrotnie poświęcał swoją uwagę sprawom szeroko pojętej dwujęzyczności na terenie dawnej Czechosłowacji i współczesnej Republiki Czeskiej, a także tematom związanym z aplikacją standardów europejskich $\mathrm{w}$ dziedzinie ochrony mniejszości narodowych oraz ochrony języków regionalnych i mniejszościowych. Żeby niepotrzebnie się nie powtarzać, w niniejszym opracowaniu skupimy uwagę wyłącznie na problematyce podwójnego nazewnictwa, a czytelników zainteresowanych omawianym zagadnieniem w szerszym kontekście autor zaprasza do zaznajomienia się z jego starszymi opracowaniami tematu ${ }^{1}$.

Swe rozważania na temat podwójnego nazewnictwa na ziemi cieszyńskiej, a później na terenie Zaolzia, rozpoczniemy w czasach, kiedy należała ona do monarchii habsburskiej, od 1867 roku zwanej Austro-Węgrami. Korzeni problemu należy szukać $\mathrm{w}$ procesie przekształcania się tradycyjnego społeczeństwa feu-

${ }^{1}$ Szczególnie chodzi o następujące pozycje: Pałka, Szymeczek, 2005; Szymeczek, 2008; 2009; 
dalnego w nowoczesne społeczeństwo obywatelskie. Właśnie stosowanie języka narodowego w przestrzeni publicznej jest jednym z przejawów egzekwowania praw politycznych w nowoczesnym państwie obywatelskim. Z powyższych względów pierwsze informacje na temat rozpatrywanego zagadnienia znajdujemy w połowie XIX wieku. Już rewolucyjny sejm ustawodawczy, który z powodu rewolucyjnych zamieszek na ulicach wiedeńskich w czasie Wiosny Ludów 1848-1849 rezydował pewien czas w morawskim Kromierzyżu (Kroměř́žz), w § 21 wniosku praw zasadniczych z 1849 roku zapewniał równorzędność języków stosowanych w poszczególnych krajach koronnych. Cała inicjatywa ustawodawcza czasów rewolucyjnych później upadła, jednak ustawa praw zasadniczych z 1867 roku powróciła do tego tematu i w swej treści zawarła niemal identyczne brzmienie na temat stosowania języków w poszczególnych krajach Przedlitawii. Różnica polegała tylko na tym, że prawodawstwo z roku 1849 ,zapewniało" równość języków w krajach koronnych, a to z roku 1867 „uznawało” taką równość ${ }^{2}$. W Austrii (Przedlitawii) nie ustanowiono żadnego języka państwowego, ponieważ urzędowym językiem był zawsze język lub języki zwykle stosowane w poszczególnych ziemiach koronnych (Landesübliche Sprache). Austria zrezygnowała również $\mathrm{z}$ utworzenia jakiegoś narodu państwowego, z perspektywy całego państwa nie posiadała żadnych mniejszości narodowych, gdyż mniejszość nie może być tam, gdzie równocześnie nie ma żadnej większości. Żadna z żyjących tu grup narodowych (nawet Niemcy) nie posiadała w ogólnym rozrachunku statystycznej większości (Rychlík, 1918a, s. 33). Mniejszości były tylko w poszczególnych krajach koronnych.

Na brzmienie paragrafów ustawy zasadniczej powoływali się obrońcy stosowania dwujęzycznych tabliczek (polsko-niemieckich) nazw ulic w Cieszynie. W 1892 roku napisy polskie na ulicach cieszyńskich zostały przez wydział gminny skasowane i pozostały tylko napisy niemieckie. Wniesiono przeciwko temu podpisany przez wielu obywateli protest do c.k. starostwa w Cieszynie. Uskarżano się, że był to wybieg obcych urzędników niemieckich i cieszyńskich żydowskich fabrykantów, Morisa Fasala i Karola Kohna („Przegląd Polityczny”, 11.12.1892, s. 90). W piśmie protestacyjnym broniono żądania pozostawienia tabliczek dwujęzycznych za pomocą następujących argumentów:

- liczba mieszkańców Cieszyna pokazuje, że Niemców jest tylko nieznacznie więcej (7664), Polacy zaś w liczebności im prawie dorównują (6170), a Czechów jest w mieście 599;

— w okolicy miasta znajdują się zupełnie polskie wioski, a mieszkańcy tych wiosek często odwiedzają Cieszyn;

— dotychczasowe tabliczki były dwujęzyczne niemiecko-polskie;

— tabliczki mają służyć całej ludności, a wiele osób języka niemieckiego nie rozumie;

${ }^{2}$ Ustawa nr 142/1867 z dnia 21 grudnia 1867 r. o zasadniczych prawach obywatelskich. Staatsgrundgesetz vom 21. Dezember 1867, über die allgemeinen Rechte der Staatsbürger für die im Reichsrathe vertretenen Königreiche und Länder, Reichs-Gesetz-Blatt für das Keiserthum Oesterreich, Jahrgang 1867, s. 396-398. Więcej na ten temat w Urban, 1982, s. 223. 
- opuszczenie nazw polskich to „pokrzywdzenie praw politycznych ludności polskiej miasta Cieszyna, która według istniejących ustaw ma niezaprzeczone prawo do tego, aby język polski z życia publicznego nie był wykluczony, co też uznają władze rządowe w praktyce, ponieważ napisy urzędów cesarskich umieszczone są we wszystkich językach krajowych” („Przegląd Polityczny”, 22.04.1894, s. 29);

- opuszczenie nazw polskich ,jest wyzuciem ludności polskiej z dotychczasowego posiadania” („Przegląd Polityczny”, 22.04.1894, s. 29).

Uchwała znacznie rozgoryczyła ludność polską i przyczyniła się do naruszenia spokojnego współżycia obu narodowości.

Starostwo cieszyńskie oddało protest do rozpatrzenia wydziałowi gminnemu, wychodząc z założenia, że to jego kompetencja. Wydział gminny podtrzymał swoją uchwałę i zostały tylko tabliczki niemieckie. Po czym złożono rekurs do wydziału krajowego. Sprawa jeszcze w 1894 roku nie była załatwiona („Przegląd Polityczny”, 22.04.1894, s. 29). W cieszyńskich gminach polskojęzycznych dominował język polski, również w przestrzeni publicznej. Do oznakowania urzędów państwowych stosowano nazwy dwujęzyczne niemiecko-polskie, a na pograniczu językowym czesko-polskim obecny był w przestrzeni publicznej również język czeski. Sklepy czy filie spółdzielni spożywców w Zagłębiu Ostrawsko-Karwińskim nierzadko oznaczone były trójjęzycznie. Stan taki trwał aż do rozpadu Austro-Węgier.

Republika Czechosłowacka powstała 28 października 1918 roku. W języku czeskim na określenie zmian, jakie przebiegły w tym dniu, stosowane jest wyrażenie ř́jnový prevrat, co na polski można by z pewną dawką fantazji przetłumaczyć jako „październikowy przewrót” czy „zwrot”, czyli wprowadzenie nowych porządków przy zachowaniu starych układów. Zdaniem autora określenie to jest bardzo trafne. Republika Czechosłowacka nie powstała bowiem na fali rewolucyjnej, nie był to zamach stanu niszczący stary ład i wprowadzający nowe zasady istnienia państwa, chodziło raczej o spokojny sposób przejęcia wszystkich starych zasad funkcjonowania państwa, tyle że teraz w innej odsłonie, w nowych realiach ${ }^{3}$. Nowa republika przejęła nie tylko funkcjonujący system, na jej barki spadła również konieczność zmierzenia się z problematyczną schedą po dawnej Austrii. Do trudnych kwestii należał niewątpliwie fakt, że — podobnie jak dawniej w Austrii — również w nowo powstałej Czechosłowacji żyły liczne grupy narodowe, przy czym żadna $\mathrm{z}$ nich, nawet Czesi, nie posiadała w ogólnym rozrachunku statystycznej większości $(50 \%)^{4}$. Problem narodowościowy i idący za nim problem językowy były

${ }^{3}$ Dotyczyło to również prawa językowego. Bezpośrednio po powstaniu Czechosłowacji obowiązywały w nowym państwie nadal stare austriackie przepisy prawne. Tymczasowa konstytucja (ustawa nr 37/1918 Sbírky zákonů a nařízení, dalej: Sb. z. a n.) spraw językowych nie rozwiązywała. Nadal zatem obowiązywał krótki artykuł XIX ustawy zasadniczej o podstawowych prawach państwowych obywateli z 21 grudnia 1867 r. (ustawa nr 142/1867).

${ }^{4}$ Charakterystyczną cechą nowego państwa czechosłowackiego było zróżnicowanie jego obywateli pod względem narodowościowym. Liczyło ono, według pierwszego oficjalnego spisu ludności z 1921 roku, 13374364 mieszkańców. Obok obywateli narodowości czeskiej i słowackiej zamieszkiwały go potężne liczebnie grupy Niemców (3 123 568), Węgrów (745 431), Rusinów (Wielkorusini, 
dla nowego państwa zasadniczym, fundamentalnym wyzwaniem, które wymagało priorytetowego rozwiązania i miało w przyszłości przesądzić o wzlocie lub upadku całego państwa. Pod tym względem ciekawe jest, że pierwszym kolektywnym przejawem woli narodu czeskiego na samym początku nowej republiki było niszczenie i usuwanie napisów niemieckich z miejsc publicznych (Klimek, 2000, s. 16). Trzeba jednak uczciwie przyznać, że Czesi w takim działaniu nie byli odosobnieni. Podobne zjawiska miały miejsce na ziemi cieszyńskiej. Jak donosiła „Gwiazdka Cieszyńska”: „Zrywanie czeskich napisów na pograniczu czesko-polskim miało zajść w kilku miejscowościach w ostatnich dniach. Uprasza się rodaków, żeby podobnych wykroczeń się ustrzegli, gdyż one mogą zamęcić dobry stosunek, jaki pomiędzy Polakami i Czechami koniecznie panować powinien” (,Gwiazdka Cieszyńska", 12.11.1918, s. 4). Dalej gazeta nawołuje do spokoju i zaniechania takich działań przez zaczekanie do definitywnego rozstrzygnięcia sprawy cieszyńskiej przez Pragę i Warszawę. Ostatecznie rozstrzygnięcie sprawy cieszyńskiej nie zapadło ani w Pradze, ani w Warszawie, tylko w Paryżu. Dnia 28 lipca 1920 roku po kilkutygodniowych rozmowach prowadzonych w belgijskim kurorcie Spa Rada Ambasadorów zwycięskich mocarstw, jako arbiter sprawy cieszyńskiej, ogłosiła w Paryżu werdykt o podziale Śląska Cieszyńskiego między Czechosłowację i Polskę. Granicą stała się rzeka Olza. Po stronie czechosłowackiej zostało według niektórych szacunków około 150000 Polaków. Czeskie statystyki wykazywały liczbę Polaków o połowę mniejszą.

Konferencja pokojowa w Paryżu w trosce o losy mniejszości narodowych w Republice Czechosłowackiej umieściła w traktatach pokojowych podpisanych z Niemcami (Wersal, 28 czerwca 1919 roku) i z Austrią (St. Germain-en-Laye, 10 września 1919 roku) postanowienia zobowiązujące Czechosłowację do podpisania dodatkowej umowy z głównymi mocarstwami, w której zamieszczone zostaną prawa mniejszości zamieszkałych w Czechosłowacji. Umowę tę podpisała Czechosłowacja dnia 10 września 1919 roku, równocześnie z traktatem pokoju w St. Germain (Sworakowski, 1937, s. 188). Była to tak zwana umowa o ochronie mniejszości, która nakłada na Czechosłowację obowiązek zapewnienia mniejszościom narodowym określonych praw. Gwarantem umowy została Liga Narodów, a jej najważniejsze postanowienia weszły do Konstytucji Czechosłowacji. Konstytucja Czechosłowacji została uchwalona 29 lutego 1920 rokus. Niektórzy historycy oceniają Konstytucję bardzo pozytywnie, podkreślają, że w pełni zapewniała prawa mniejszości narodowych, i doceniają jej trwałość, czego dowodem miał być fakt, że w czasie trwania pierwszej Republiki Czechosłowackiej nie została w niej zmieniona

no również Żydom, przez co wachlarz struktury narodowościowej państwa rozszerzył się o jeszcze jedną dość liczną pozycję (180 855). Stan według oficjalnego spisu ludności z 15 lutego 1921 roku (Československá statistika..., 1924, tabela 50: Národnost československých státních př́íslušníků, I., s. 60). Całkowita liczba wyznawców judaizmu wynosiła w 1921 roku w całej Czechosłowacji 354 300. Z liczby tej według ustaleń Radki Čermákovej 73300 osób zadeklarowało narodowość czechosłowacką, 49100 niemiecką, 29400 węgierską, 3700 rosyjską, 2000 polską i 180700 żydowską (zob. Čermáková, 2003).

${ }^{5}$ Na temat przyjmowania ustawy więcej w: Kárník, 2017, s. 106-113. 
ani jedna literka, w odróżnieniu od konstytucji niemieckiej, austriackiej, jugosłowiańskiej, rumuńskiej czy polskiej (Klimek, 2000, s. 148). Historycy zwracają też uwagę na fakt, że była inspiracją dla twórców Konstytucji Republiki Czeskiej z 1993 roku. Eva Broklová, czołowa znawczyni porządku konstytucyjnego pierwszej (międzywojennej) republiki nazwała ją ,przyzwoitą ustawą dla przyzwoitych ludzi” (Klápště, Šedivý, 2019, s. 227). Jakub Rákosník natomiast wyraża odmienną opinię na temat konstytucji. Jego zdaniem niezmienność konstytucji w politycznych warunkach pierwszej republiki czechosłowackiej była wynikiem obaw establishmentu władzy, dla którego typowe były chwiejne koalicje, aby dążenia o naprawę problematycznych zapisów konstytucji nie spowodowały niemożliwej do opanowania lawiny żądań, szczególnie ze strony mniejszości narodowych, których realizacja mogłaby doprowadzić do destrukcji Czechosłowacji jako unitarnego państwa demokratycznego (Klápště, Šedivý, 2019, s. 227).

Równocześnie z konstytucją, po bardzo burzliwej debacie, w nerwowej atmosferze okresu przedwyborczego została uchwalona ważna z punktu widzenia mniejszości narodowych ustawa językowa, która stała się podstawą praw językowych w Republice Czechosłowackiej w okresie międzywojennym (nr 122/1920 Sb. z. a n. $)^{6}$. Ustawa językowa była integralną częścią konstytucji w postaci rozwinięcia art. 129 (Miszewski, 2013, s. 50). Określała ona język czeski i słowacki jako jeden język czechosłowacki, który był ,państwowym i oficjalnym językiem republiki" (Tóth, Novotný, Stehlík, 2012, s. 277). Wzajemne stosowanie obu języków regulował § 4 ustawy językowej. Według tego paragrafu język czeski miał być stosowany na ziemiach czeskich, a słowacki na Słowacji (Rychlík, Pančev, 2013, s. 416). Poza tym ustawa określała, że w powiatach zamieszkałych przez co najmniej $20 \%$ mniejszości w kontaktach z urzędami i przed sądami dopuszczalny był język tejże mniejszości (Tóth, Novotný, Stehlík, 2012, s. 283). W porównaniu z prawodawstwem austriackim był to krok wstecz. Na ziemiach czeskich język czeski został automatycznie językiem urzędowym na całym obszarze kraju, to znaczy również w gminach, gdzie żadnych Czechów nie było, podczas gdy języki niemiecki w Sudetach i polski na Zaolziu mogły być stosowane w komunikacji urzędowej tylko tam, gdzie Niemcy względnie Polacy stanowili $20 \%$ populacji (Rychlík, Pančev, 2013, s. 417). W 1926 roku zostały przyjęte przepisy wykonawcze do omawianej ustawy w postaci rozporządzenia rządowego $\mathrm{nr}$ 17/1926 Sb. z. a n. ${ }^{7}$ Regulowały one m.in. stosowanie nazw miast i wiosek, przystanków kolejowych, linii autobusowych, urzędów państwowych i podobnych spraw, a także nazw prywatnych przedsiębiorstw i sklepów w języku mniejszości. Wszystkie takie

\footnotetext{
${ }^{6}$ Sb. z. a n., Roč. 1920, Částka XXVI. Vydaná dne 6. března 1920. Čís. 122. Zákon ze dne 29. února 1920 podle $\S 129$ ústavní listiny, jímž se stanoví zásady jazykového práva v republice Československé, s. 268-269.

${ }^{7}$ Sb. z. a n., Roč. 1926, Částka 9. Vydaná dne 4. února 1926. Čís. 17. Vládní nařízení ze dne 3. února 1926, jímž se provádí ústavní zákon jazykový pro obor ministerstva vnitra, spravedlnosti, financi, průmyslu, obchodu a živností, veřejných prací a veřejného zdravotnictví a tělesné výchovy, pro veřejné kompetence, podléhající těmto ministerstvům v republice Československé jakož i pro úruady místní samosprávy, s. 57-76.
} 
urzędy i instytucje musiały być oznaczone w języku państwowym. Podanej na pierwszym miejscu nazwie czeskiej lub słowackiej mogła towarzyszyć nazwa w języku mniejszości, przy tym jednak wielkość pisma musiała być mniejsza niż oznaczenie w języku państwowym. Artykuł 99 przepisów wykonawczych umożliwiał zaprowadzenie oznakowania tablicami dwujęzycznymi (w języku państwowym i mniejszościowym) urzędów państwowych i instytucji publicznych, ale tylko w tych miejscowościach, w których powyżej 20\% mieszkańców deklarowało przynależność do konkretnej mniejszości narodowej (Rychlík, 2018b, s. 154). W praktyce podwójne nazwy obowiązywały instytucje oraz firmy prywatne również w tych miejscowościach, gdzie żadnych Czechów nie było.

Oznakowanie ulic mogło być dwujęzyczne, ale nazwa czeska musiała znajdować się na pierwszym miejscu. Ustawa nr 266/1920 Sb. z. a n. o nazwach miast, gmin, osad i ulic oraz oznakowaniu gmin miejscowymi tabliczkami i numerami domów (zákon o názvech měst, obcí, osad a ulic, jakož i označování obcí místními tabulkami a číslování domů) zakazywała stosowania nazewnictwa, które nie było zgodne z czeską (czechosłowacką) interpretacją historii i zewnętrznych stosunków narodu czechosłowackiego (Horony, Orosz, Szalay, 2015). Szczególnie zaś chodziło o nazwy upamiętniające osoby, które w jakikolwiek sposób przejawiały wrogą postawę wobec narodu czechosłowackiego lub narodów zamieszkujących republikę, bądź nazwy utrwalające pamięć o wydarzeniach o charakterze antypaństwowym. Po obwieszczeniu tej ustawy gminy miały obowiązek w terminie do jednego miesiąca usunąć i bez śladu zniszczyć wszystkie przejawy niewłaściwego nazewnictwa (Rychlík, 2018, s. 153). Legalne zmiany nazw niemieckich, węgierskich i polskich miast i gmin na nazwy czeskie i słowackie przeprowadzano już od połowy marca 1920 roku (Heimannová, 2020, s. 71). Nowe nazwy były dla miejscowych często niezrozumiałe. W czasie upadku czechosłowackiej państwowości i przyłączenia Zaolzia do Polski jesienią 1938 roku żywiołowo usuwano tabliczki czeskie z przestrzeni publicznej. Władze polskie na Zaolziu nie prowadziły polityki stosowania podwójnego nazewnictwa.

Chociaż po II wojnie światowej czechosłowacka Ustawa Majowa z 1948 roku w rozdziale 2., ustępie 1. mówiła, że Republika Czechosłowacka jest jednolitym państwem dwóch równoprawnych słowiańskich narodów Czechów i Słowaków, a Koszycki Program Rządowy określał, że językami służbowymi w armii czechosłowackiej są języki czeski i słowacki (Petráš, 2007, s. 220), to nie było zakazów stosowania w życiu publicznym innego języka niż czeski. Mimo wszystko w latach 1945-1954 używanie języka polskiego na Zaolziu było ograniczane. Dwujęzyczność i podwójne nazewnictwo na Zaolziu obowiązywało na ograniczonych warunkach. Regulacji spraw dwujęzyczności domagali się polscy komuniści z kierownictwa Polskiego Związku Kulturalno-Oświatowego. W praktyce bowiem tylko głos komunistów się liczył i mógł mieć jakieś znaczenie. Dnia 14 czerwca 1955 roku Okręgowa Rada Narodowa (dalej: ORN) w Ostrawie, poniekąd pozbywając się własnej odpowiedzialności, wydała rozporządzenie, w którym odpowiedzialność za wprowadzenie dwujęzyczności w komunikacji z urzędami oraz rozmieszczanie tablic z napisami dwujęzycznymi przekazała do gestii powiatowych rad narodowych w Karwinie i Czeskim Cieszynie (Petráš, 2007, s. 215). 
Ze względu na brak przepisów wykonawczych zasięg dwujęzyczności i podwójnego nazewnictwa różnił się w poszczególnych gminach, a wdrażaniu dwujęzyczności towarzyszyły znaczna improwizacja i brak koordynacji. W nazwach dwujęzycznych pojawiały się błędy gramatyczne i nieścisłości językowe. Ważnym momentem w kwestii rozwiązywania sprawy dwujęzyczności w czasach komunistycznej Czechosłowacji było rozporządzenie ORN w Ostrawie z dnia 11 grudnia 1962 roku. Na jego mocy dwujęzyczność można było wprowadzić w 46 gminach i miastach powiatów Karwina i Frydek-Mistek. Dwujęzyczne napisy miały zostać umieszczone na budynkach urzędów państwowych i samorządowych oraz na sklepach, które w czasach komunistycznej Czechosłowacji funkcjonowały wyłącznie jako państwowe.

Podczas odwilży politycznej w latach 60., a w szczególności w 1968 roku przedstawiciele mniejszości narodowych (nie tylko Polacy, lecz także Niemcy, Węgrzy, Ukraińcy, Rusini i Romowie) głośno zaczęli domagać się swych praw narodowych. W odpowiedzi na ich działania w październiku 1968 roku została przyjęta ustawa o mniejszościach narodowościowych, która nie wprowadziła jednak zasadniczych zmian w omawianej kwestii. Po zdławieniu w 1968 roku prób reformy socjalizmu w Czechosłowacji nastąpił okres normalizacji, czyli powrotu do komunistycznej formy sprawowania władzy, a z nim powrót do komunistycznej polityki mniejszościowej z lat 50. i początku lat 60 . Przez cały okres normalizacji podwójne nazewnictwo było w ograniczonym zakresie tolerowane, praktycznie sprowadzało się to do utrzymania zastanego stanu. Napisy pozostały, ale żywy język polski w urzędach zanikł do tego stopnia, że pod koniec lat 80. XX wieku tradycja prowadzenia urzędowej korespondencji w języku polskim czy posługiwania się tym językiem w urzędach prawie zamarła. Podwójne nazewnictwo czasów komunistycznych nie dotyczyło tablic wjazdowych do poszczególnych gmin oraz oznakowania ulic.

Po zwycięstwie aksamitnej rewolucji w 1989 roku, a następnie w utworzonej 1 stycznia 1993 roku Republice Czeskiej zmieniły się warunki kształtujące życie społeczno-polityczne. Dla społeczności polskiej pojawiły się zupełnie nowe możliwości działania. W pierwszych latach demokracji dwujęzyczność i podwójne nazewnictwo nie były dla Polaków na Zaolziu istotnym tematem. Przedstawiciele mniejszości zajmowali się sprawami związanymi z transformacją ustrojową i budowaniem nowych struktur organizacyjnych mniejszości w nowych warunkach demokratycznych. W tym samym czasie z budynków państwowych i gminnych urzędów były usuwane stare tablice będące pozostałością minionego reżimu oczywiście wraz z napisami dwujęzycznymi. Nowe tablice były już tylko czeskie. Tylko nieliczni sprzeciwiali się temu procesowi. Największy rozgłos medialny zdobyło zajście, które miało miejsce w Cierlicku. Miejscowy wójt narodowości polskiej usunął stare oznakowania urzędu z okresu komunistycznego, a wprowadził nowe, w pełni dwujęzyczne, co wzbudziło sprzeciw społeczności większościowej i władz powiatowych. Dwujęzyczne napisy się obroniły, a cała ,afera” spropagowała temat podwójnego nazewnictwa w polskim środowisku i stała się dla miejscowych działaczy wyzwaniem. 
Wówczas już jednak zmienił się klimat w całym społeczeństwie, które zaczęło coraz częściej posługiwać się hasłami proeuropejskimi. Dnia 30 czerwca 1993 roku Republika Czeska została członkiem Rady Europy. W związku z członkostwem w tej międzynarodowej organizacji, która zajmuje się m.in. ochroną praw człowieka, Republika Czeska została sygnatariuszem kilku znaczących dokumentów prawa międzynarodowego. Dokumenty te są zgodnie z rozdziałem 10. Konstytucji Republiki Czeskiej nadrzędnymi dokumentami wobec norm prawnych prawodawstwa wewnątrzkrajowego. W sprawie podwójnego nazewnictwa kluczową rolę odgrywały dwa dokumenty europejskie: Konwencja Ramowa o ochronie mniejszości narodowych, a przede wszystkim Europejska Karta języków regionalnych lub mniejszościowych.

Ratyfikacja Konwencji Ramowej była przełomowym momentem w procesie kształtowania ochrony praw mniejszości narodowych w Republice Czeskiej po 1989 roku, a Europejska Karta języków wytworzyła ramy prawne do wprowadzenia standardów europejskich w dziedzinie dwujęzyczności i podwójnego nazewnictwa. Konwencja Ramowa obowiązuje w Republice Czeskiej od 1 kwietnia 1998 roku, Karta języków zaś od 1 marca 2007 roku. Izba Poselska Parlamentu Republiki Czeskiej wraz z wyrażeniem zgody na ratyfikację Konwencji Ramowej przyjęła towarzyszące ratyfikacji rozporządzenie (Usnesení Poslanecké Sněmovny Parlamentu ČR nr 561/1997 z 6.11.1997), którym zobowiązała rząd Republiki Czeskiej do przeprowadzenia analizy norm prawnych mających wpływ na życie mniejszości narodowych i zaproponowanie potrzebnych zmian, które dostosowałyby ustawodawstwo czeskie do tez zawartych w Konwencji Ramowej. To stało się impulsem do rozpoczęcia prac nad brzmieniem ustawy $\mathrm{nr}$ 273/2001 Sb. o prawach członków mniejszości narodowych, które uwieńczone zostały przez przyjęcie tejże ustawy ${ }^{8}$ przez Izbę Poselską Parlamentu Republiki Czeskiej w dniu 10 lipca 2001 roku oraz nowelizację niektórych ustaw, szczególnie ustawy nr 128/2002 o gminach9.

W myśl ustawy mniejszościowej członkom mniejszości narodowej tradycyjnie i długotrwale zamieszkującym obszar Republiki Czeskiej przysługuje m.in. prawo do tego, by nazwy miejscowości, w których mniejszość żyje, części tychże miejscowości, ulic, budynków użyteczności publicznej, budynków administracji publicznej i lokali wyborczych występowały także w języku mniejszości (§ 8 ust. 1). Natomiast ustawa $\mathrm{nr} 128 / 2002$ o gminach precyzuje, jak to prawo należy w praktyce realizować. Na podstawie wyżej wymienionej ustawy (§ 29) można wprowadzić oznakowanie nazwy gminy, jej części, ulic i innych miejsc publicznych oraz oznakowanie budynków organów państwowych i samorządowych również w języku mniejszości narodowej. Podwójne nazewnictwo można wprowadzić w gminie, którą zamieszkuje więcej niż 10\% Polaków z ogólnej liczby mieszkańców. Krok taki początkowo uwarunkowany był petycją w sprawie

${ }^{8}$ Zákon č. 273/2001 Sb. o právech př́islušníků národnostních menšin a o změně některých zákonů. https://www.zakonyprolidi.cz/cs/2001-273 [dostęp: 20.02.2020]. Omówienie ustawy szerzej w: Szymeczek, 2011.

9 Zákon č.128/2000 Sb. o obcích. https://www.zakonyprolidi.cz/cs/2000-128 [dostęp: 20.02.2020]. 
dwujęzycznych nazw, z wymaganym poparciem co najmniej 40\% pełnoletnich obywateli narodowości polskiej. Konieczność przeprowadzania petycji poprzedzającej wprowadzenie podwójnego nazewnictwa nie spełniała jednak oczekiwań mniejszości polskiej. Dnia 7 listopada 2003 roku zebrało się w Czeskim Cieszynie 21 prezesów organizacji polskich na Zaolziu i podpisało pismo, które wysłano do parlamentu czeskiego z żądaniem zniesienia konieczności przeprowadzania petycji. Argumentowano, że w gminach, gdzie działacze polscy przystąpili do zbierania podpisów pod petycją, dochodziło do wielu antypolskich wystąpień. Na internetowych stronach regionalnych gazet i różnych blogów pojawiły się tysiące wpisów wymierzonych przeciwko Polakom. Władze były zaskoczone taką reakcją. Fala ksenofobicznych zachowań stała się dobrym argumentem dla przeciwników petycji. Po licznych protestach zrezygnowano z wymogu przeprowadzania petycji i zastąpiono go warunkiem, że organizacje polskie same muszą z takim wnioskiem wystąpić, po czym musi go polecić Radzie Gminy do realizacji miejscowy Komitet ds. Mniejszości Narodowych.

Dwujęzyczne tablice zaczęły wzbudzać emocje — szczególnie tablice wjazdowe do miejscowości umieszczone przy gminnych i państwowych ciągach komunikacyjnych. Są one najbardziej wyrazistym akcentem obecności mniejszości polskiej na Zaolziu. W czasach komunistycznych dwujęzyczne tablice wjazdowe, pomimo stosowania dwujęzyczności, nie były tolerowane, toteż większość czeska musiała w czasie po odzyskaniu demokracji postrzegać ich wprowadzenie na podstawie standardów europejskich jako nieprzyjemną nowość. Stosunek określonych gmin do tablic dwujęzycznych był zależny od konkretnych układów w poszczególnych miejscowościach. W sumie można powiedzieć, że proces wprowadzania dwujęzycznych napisów rozwija się w sposób naturalny. Tam, gdzie Polacy mają wpływ na kształt polityki komunalnej i gdzie są darzeni szacunkiem, wprowadzanie tablic przebiega bez emocji, a czasami bywa nawet poprzedzone rzeczową dyskusją. W poszczególnych gminach, które zdecydowały się na wprowadzenie podwójnego nazewnictwa, używa się go w różnym zakresie. Na przykład w Czeskim Cieszynie (od 2007 roku) i Jabłonkowie dwujęzycznie oznaczono tablice wjazdowe, budynki publiczne i ulice. W Trzyńcu, pomimo żądań ze strony polskiej mniejszości, ulic dwujęzycznie nie oznaczono, są tylko tablice wjazdowe i dwujęzyczne tablice urzędów państwowych. Kiedy niejako przypadkiem oznakowano dwujęzycznie również dworzec autobusowy, władze miasta Trzyńca w ciągu jednego dnia napis ten usunęły.

W sumie dwujęzyczne tablice w różnym zakresie wprowadziło do dnia dzisiejszego przeszło 20 z 31 gmin zaolziańskich, których to dotyczy. Niekiedy procesowi temu towarzyszyła burzliwa, pełna emocji debata publiczna. Najwięcej medialnych wystąpień na temat dwujęzyczności pojawiało się w Trzyńcu. Jest to spowodowane faktem, że w mieście tym wydawane były swego czasu aż dwa lokalne czeskie periodyki („Horizont” i „Hutník”). W Jabłonkowie, Trzyńcu, Cierlicku, Czeskim Cieszynie czy Gnojniku odnotowano też akty narodowo motywowanego wandalizmu. Na porządku dziennym było zamazywanie i niszczenie 122 dwujęzycznych tablic, co władze czeskie uważały wyłącznie za akty wandalizmu, 
a nie przejawy wrogości wobec Polaków. Co ciekawe, pomimo tak licznych szkód, policji nie udało się nikogo schwytać. Niszczenie tablic odbiło się głośnym echem w mediach i to nie tylko w polskiej prasie lokalnej („Głos Ludu”), lecz także w ogólnokrajowych pismach polskich i czeskich („Lidové noviny”, „Mladá fronta dnes") ${ }^{10}$. Sprawą niszczenia podwójnych napisów osobiście zajęli się również prezydenci Rzeczpospolitej Polskiej Lech Kaczyński ${ }^{11}$ i Republiki Czeskiej Václav Klaus $^{12}$. Niekiedy formy protestu przeciwko napisom dwujęzycznym przybierały kuriozalny charakter. W Czeskim Cieszynie jeden z przeciwników dwujęzyczności umieścił obok czesko-polskiej tabliczki dwie dodatkowe, wyglądające dokładnie tak samo jak oryginał, ale ze słowacką i niemiecką nazwą. Miasto uznało to za prowokację i właścicielowi płotu, na którym zawisły tabliczki (czesko-niemiecka i czesko-słowacka), nakazało ich usunięcie. Właściciel publicznie oświadczył, że jego zdaniem nie popełnił żadnego wykroczenia i tablic zdjąć nie zamierza. W prasie tłumaczył, że ,chciał wywołać dyskusję, dlaczego o tym, która mniejszość narodowa ma prawo do dwujęzyczności, mają decydować wyłącznie suche liczby w ustawach"13. Tablice wiszą na płocie do dnia dzisiejszego.

Cała sprawa wprowadzania podwójnego nazewnictwa na Zaolziu ma jeszcze jeden nieprzyjemny aspekt. Postulaty mniejszości polskiej w zakresie podwójnego nazewnictwa wnosił $\mathrm{w}$ imieniu mniejszości polskiej do czeskich władz Kongres Polaków w Republice Czeskiej. Przedstawiciele Kongresu prowadzili swe działania $\mathrm{w}$ formie polityki gabinetowej, bez masowego rozgłosu. Ta metoda była akceptowana przez czynniki rządowe, którym odpowiadało załatwianie tych spraw bez niepotrzebnego rozgłosu. Problem polegał na tym, że wskutek tego każde osiągnięcie mniejszości polskiej w tym zakresie nie było traktowane jako wprowadzanie standardów europejskich, tylko jako działanie wymuszone na czeskich władzach przez grupę negocjatorów, którzy zdaniem czeskiej lokalnej większości nie mieli poparcia wśród polskiej mniejszości, gdyż takie poparcie nie było nigdzie widoczne. Postulatom polskim zgłaszanym do władz nie towarzyszyły debaty publiczne, zebrania czy kampanie oświatowe w mediach. Jeżeli doszło do jakiejś debaty negocjatorów z czeskim społeczeństwem — tak jak miało to miejsce w obecności ministra do spraw praw człowieka (ministr pro lidská práva) Michaela Kocába w Śmiłowicach 18 lutego 2010 roku - to efekty były żenujące. Polskie racje zostały w ostry sposób odrzucone przez czeskich aktywistów, a pozostał niesmak i obustronny wstręt ${ }^{14}$. Czeskie społeczeństwo większościowe na Zaolziu doszło do przekonania, że do wprowadzenia podwójnego nazewnictwa dąży tylko grupka sfanatyzowanych wariatów, która swymi urojonymi fantazjami pragnie

${ }^{10}$ Wśród licznych głosów medialnych znalazł się m.in. następujący: Ničení polských nápisů na Těšínsku — Potížemi v soužití Čechů s Poláky se zabývali i prezidenti. „Čeští politici mlčí a to je zle” („Lidové noviny”, 23.01.2010, s. 6).

${ }^{11}$ „Kaczyński: Na Zaolziu zdarzają się rzeczy, które zdarzać się nie powinny” („Głos Ludu”, 23.01.2010, s. 1).

12 „Krizi s Poláky pojede řešit sám Klaus” („Lidové noviny”, 23.01.2010, s. 6).

13 „To nie była prowokacja!” („Głos Ludu”, 6.01.2009, s. 4).

14 „Michael Kocáb se zajímal o národnostní menšiny” („Hutník”, 24.02.2010, s. 1, 3); „Kocáb mapoval národnostní situaci” („Horizont”, 23.02.2010, s. 2). 
rozbudzić waśnie narodowe między Polakami i Czechami na Zaolziu ${ }^{15}$, by wykorzystać je do własnych celów. Wydaje się, że Polaków i Czechów czeka tu jeszcze długa droga do wzajemnego zbliżenia poglądów. Czesi na Zaolziu traktują „swoich Polaków" jako grupę mniejszościową, która jest częścią czeskiego społeczeństwa obywatelskiego. Ogół tego społeczeństwa nie widzi potrzeby roztrząsania spraw związanych z narodowością, inne zaś podejścia, zmierzające w kierunku rozwoju życia kulturowego na bazie narodowej, uznaje za pomyłkę lub uzurpatorstwo. Do tej kategorii wliczany bywa bez wątpienia również temat podwójnego nazewnictwa.

\section{Bibliografia}

\section{Źródła drukowane}

Československá statistika - svazek 9. Sčitáni lidu v republice Československé ze dne 15. února 1921, 1924. Díl I., Praha.

Reichs-Gesetz-Blatt für das Keiserthum Oesterreich, Jahrgang 1867.

Sbírky zákonů a nařízení Republiky Československé 1918—1920, 1926.

\section{Prasa}

„Dnes — magazín”, 25.02.2010, nr 8, s. 22-23.

„Głos Ludu”, 6.01.2009, s. 4.

„Głos Ludu”, 23.01.2010, s. 1.

„Gwiazdka Cieszyńska”, 12.11.1918, nr 91, s. 4.

„Horizont”, 23.02.2010, s. 2.

„Hutník”, 24.02.2010, s. 1-3.

„Lidové noviny”, 23.01.2010, s. 6.

Mácha P., 2019: Dwujęzyczność to atut. Nie dla wszystkich. „Głos” nr 88, r. LXXIV, s. 1. „Przegląd Polityczny”, 22.04.1894. Dodatek do „Rolnika Śląskiego”, nr 8, s. 29.

„Przegląd Polityczny”, 11.12.1982. Dodatek do „Rolnika Śląskiego”, nr 23, s. 90.

\section{Opracowania}

Čermáková R., 2003: Československá republika - nový stát ve středni Evropě a Židé. W: Židovská menšina v Československu ve dvacátých letech. Red. B. Soukupová, M. Zahradníková. Praha: Židovské muzeum v Praze, s. 9-20.

Heimannová M., 2020: Československo. Stát, který zklamal. Havličkův Brod: Petrkov.

Horony A., Orosz O., Szalay Z., 2015: Používáni jazyka národnostních menšin na jižním Slovensku na př́kladu veřejných nápisů od roku 1918. W: Mniejszości narodowe i prawodawstwo mniejszościowe w Europie Środkowo-Wschodniej. Historia i wspótczesność. Red. K. Nowak, J. Szymeczek. Czeski Cieszyn: Kongres Polaków w Republice Czeskiej, s. 29-50.

Kárník Z., 2017: České země v éře prvni republiky. Vznik, budováni a zlatá léta republiky (1918-1929). Praha: Libri. 
Klápště J., Šedivý I. (ed.), 2019: Dějiny Česka. Praha: NLN.

Klimek A., 2000: Velké dějiny zemí Koruny české, svazek XIII 1918-1929. Praha-Litomyšl: Paseka.

Miszewski D., 2013: Polacy i Czesi na Śląsku Cieszyńskim w latach 1848-1945. Warszawa: Europejskie Centrum Analiz Geopolitycznych.

Pałka, E., Szymeczek J., 2005: Polityka narodowościowa Republiki Czeskiej. W: J.B. Albin, W. Baluk: Europa Środkowa dekada transformacji. Republika Czeska. Wrocław: Oficyna Wydawnicza „Arboretum”, s. 181-230.

Petráš R., 2007: Menšiny v komunistickém Československu. Právní a faktické postavení národnostních menšin v českých zemích v letech 1948-1970. Praha: VIP Books.

Rychlík J., 2018a: 1918: Rozpad Rakousko-Uherska a vznik Československa. Praha: Vyšehrad.

Rychlík J., 2018b: Multinacionální stát. W: Republika Československá 1918-1939. Red. D. Hájková, P. Horák. Praha: NLN, s. 144-161.

Rychlík J., Pančev V., 2013: Od minulosti k dnešku. Dějiny českých zemí. Praha: Vyšehrad.

Sworakowski W., 1937: Polacy na Ślasku za Olza. Warszawa: Instytut Badań Spraw Narodowościowych.

Szymeczek J., 2008: Realizacja praw polskiej mniejszości w Czechosłowacji na przykładzie dwujęzyczności i podwójnego nazewnictwa. W: Colloquium Opole 2007. Mniejszości narodowe $i$ etniczne - edukacja i kultura. Red. S. Senft, A. Trzecielińska-Polus. Opole: Państwowy Instytut Naukowy, s. 113-121.

Szymeczek J., 2009: Walka standardów europejskich z mitami czeskimi. W: Tożsamość etniczna i kulturowa Ślaska w procesie przemian. Red. H. Rusek, A. Drożdż. Wrocław-Cieszyn: Polskie Towarzystwo Ludoznawcze, s. 318-325.

Szymeczek J., 2011: Evropské standardy vzdělávání v oblasti práv národnostních menšin. Ostrava: Ostravská univerzita v Ostravě.

Szymeczek J., 2013: Stosowanie Europejskiej karty języków regionalnych lub mniejszościowych w Republice Czeskiej. W: Polityka państw narodowych wobec języka na Górnym Ślasku w XIX i XX wieku. Red. M. Lis, Ł. Jarczak, L. Drożdż. Opole: Państwowy Instytut Naukowy, s. 61-68.

Szymeczek J., 2015: Prawa mniejszości narodowych w Republice Czeskiej ze szczególnym uwzględnieniem Polaków na Zaolziu. W: Mniejszości narodowe i prawodawstwo mniejszościowe $w$ Europie Środkowo-Wschodniej. Historia $i$ współczesność. Red. K. Nowak, J. Szymeczek. Czeski Cieszyn: Kongres Polaków w Republice Czeskiej, s. $151-168$.

Tóth A., Novotný L., Stehlík M., 2012: Národnostní menšiny v Československu. Od státu národního ke státu národnostnímu. Praha: Univ. Karlova.

Urban O., 1982: Česká společnost 1848—1918. Praha: Svoboda.

\section{Źródła internetowe}

Zákon č. 273/2001 Sb. o právech př́íslušníků národnostních menšin a o změně některých zákonů. https://www.zakonyprolidi.cz/cs/2001-273 [dostęp: 20.2.2020].

Zákon č.128/2000 Sb. o obcích. https://www.zakonyprolidi.cz/cs/2000-128 [dostęp: 20.02.2020]. 